\title{
THE STATE PRESIDENT'S UNIT IN ITS CAPACITY AS CEREMONIAL GUARD
}

Lt Cdr E.M. Meyers*

The most important function of the State President's Guard is that of acting as home guard for the State President and of acting as guard of honour at ceremonial occasions. Members of such a special guard not only had to meet specific requirements in the past, but even today they are subject to strict selection requirements.

The uniform of the State President's Guard was changed recently. The new uniform, based on the current army uniform, replaces the old Republican model.

\section{Need}

On the occasion of the fifth commemoration of the birth of the Republic of South Africa in 1966, an appeal was made to the then Minister of Defence, as well as to the Commandant-General of the Defence Force, in which the establishment of a military force in special uniforms was cham- pioned. This force would be the ceremonial guard of the State President and would act as guard of honour at ceremonial occasions.

The government immediately reacted to the plea in a positive manner, and decided that the finest effort had to be made to enhance the image of the State President and to vest him with greater dignity. Subsequently, the supreme command of the Defence Force was requested to establish a State President's Guard.

\section{Establishment of the Unit}

Up to, and including State President C.R. Swart's term of office, no permanent guard existed. Since he was to retire from office on 31 May 1967, and his successor was to be sworn in on the very same day, plans were made for the Guard to appear in public for the first time on this occasion.

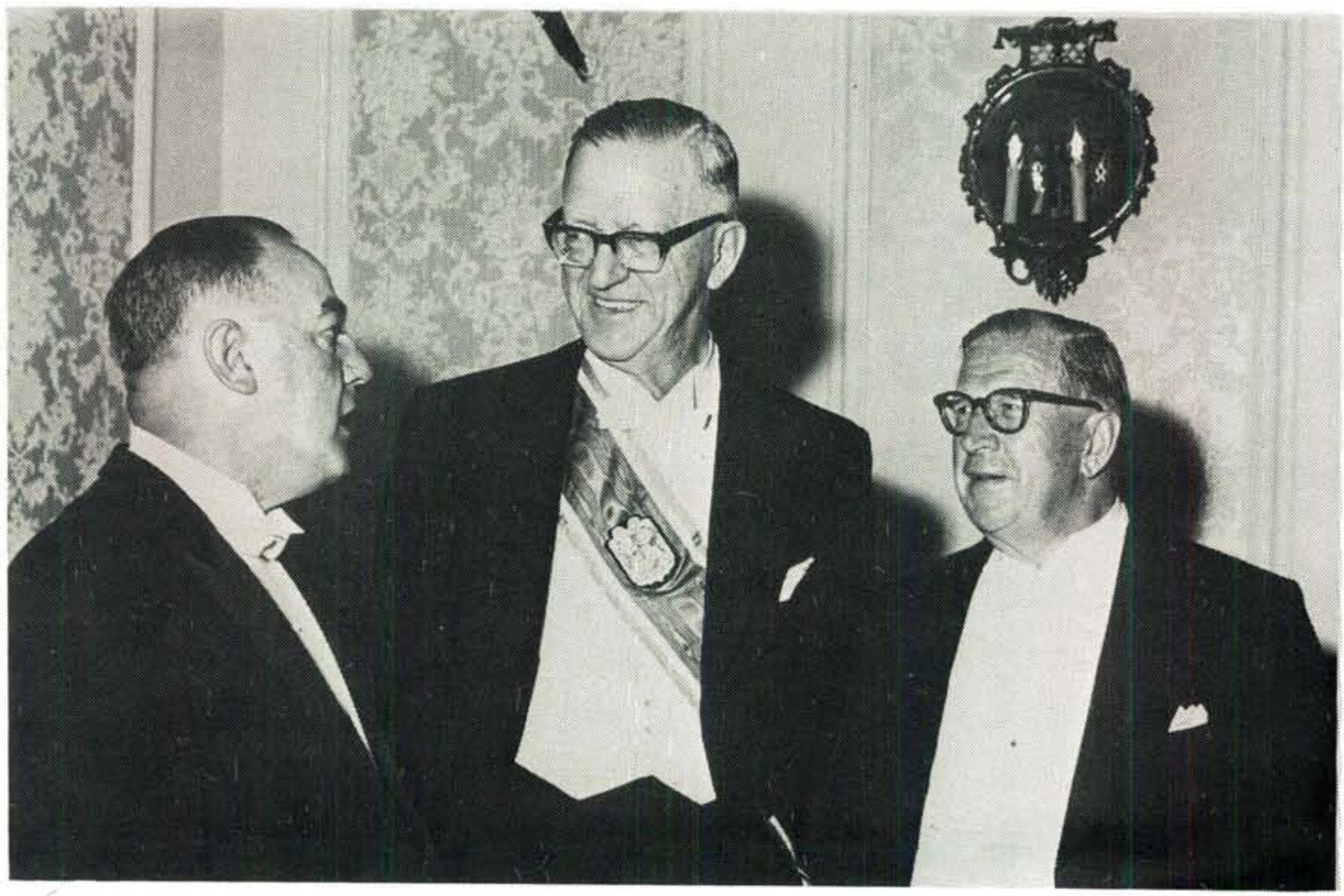

Drie Staatspresidente in gesprek met mekaar. Mnr. C.R. Swart (middel) die eerste Staatspresident gesels met die aangewese Staatspresident dr. Eben Dönges (regs) en met mnr. B.J. Vorster, 'n latere Staatspresident.

Three state presidents in conversation. Mr C.R. Swart (centre), the first State President talking to the State Presidentelect, Dr Eben Dönges (right) and Mr B.J. Vorster, a future State President. 
The Unit was established officially on 1 May 1967 and an industrious effort was made to train the specially selected servicemen who would form this guard of honour. Special uniforms had to be manufactured as quickly as possible. Due to Dr Eben Dönges, the State President elect's illness, the Guard could, however, make its first public appearance only eight months later at his state funeral.

\section{State President and Ceremonial Performances}

Including the state funerals of the first State President, Mr C.R. Swart and that of the State President-elect, Dr Eben Dönges, the State President's Guard served all the state presidents of the Republic of South Africa.

The most important ceremonial function of the State President's Guard is that of guard of honour. Appearances of the Guard in this capacity include the following: the inauguration of state presidents; visits from foreign heads of state, as well as other eminent foreign visitors; performances at the state funerals of state presidents and at certain other military funerals. Regular performances also take place at occasions

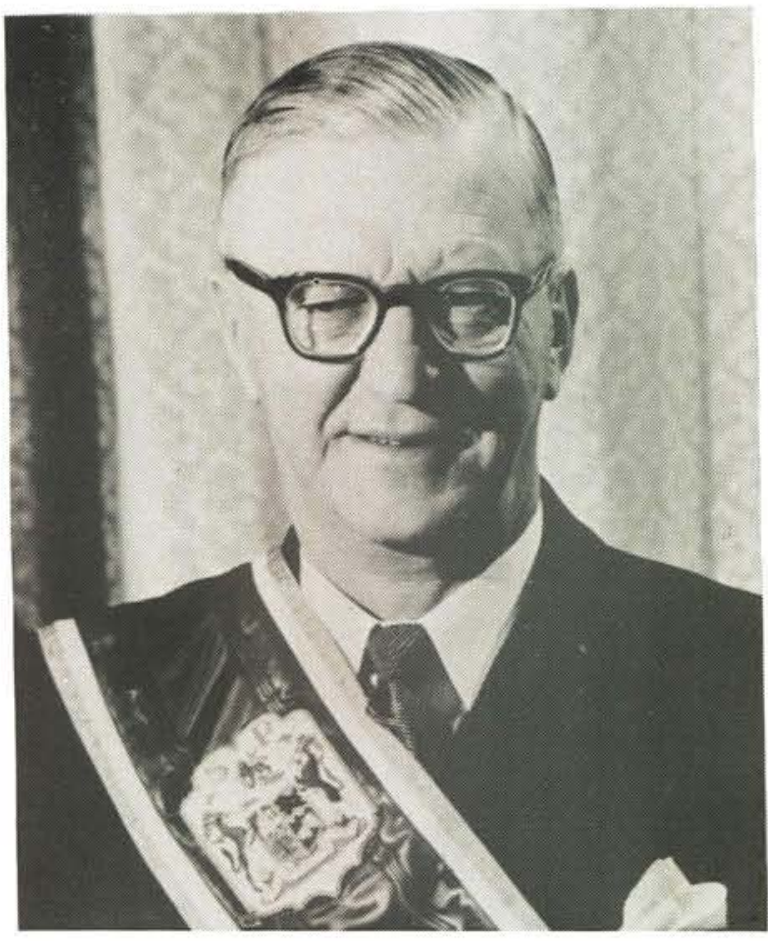

Mnr. C.R. Swart, die eerste Staatspresident wat geen permanente wag gehad het nie.

Mr C.R. Swart, the first State President, who did not have a permanent guard. when foreign ambassadors present their credentials to the State President. Other appearances are when national states officially gain independence. In addition, the Guard also performs at the official arrival and departure of the State President from various cities, especially those cities in which his official residences are situated.

\section{C.R. Swart DVD}

The political career of this first State President commenced in 1919, when he was appointed Chief Secretary of the National Party in the Orange Free State. In 1923 he became a member of the House of Assembly and in 1948 he was appointed Minister of Justice. He held this position until he was appointed as the first State President of the RSA, a post which he filled until his retirement six years later.

The State President's Guard performed only at his funeral.

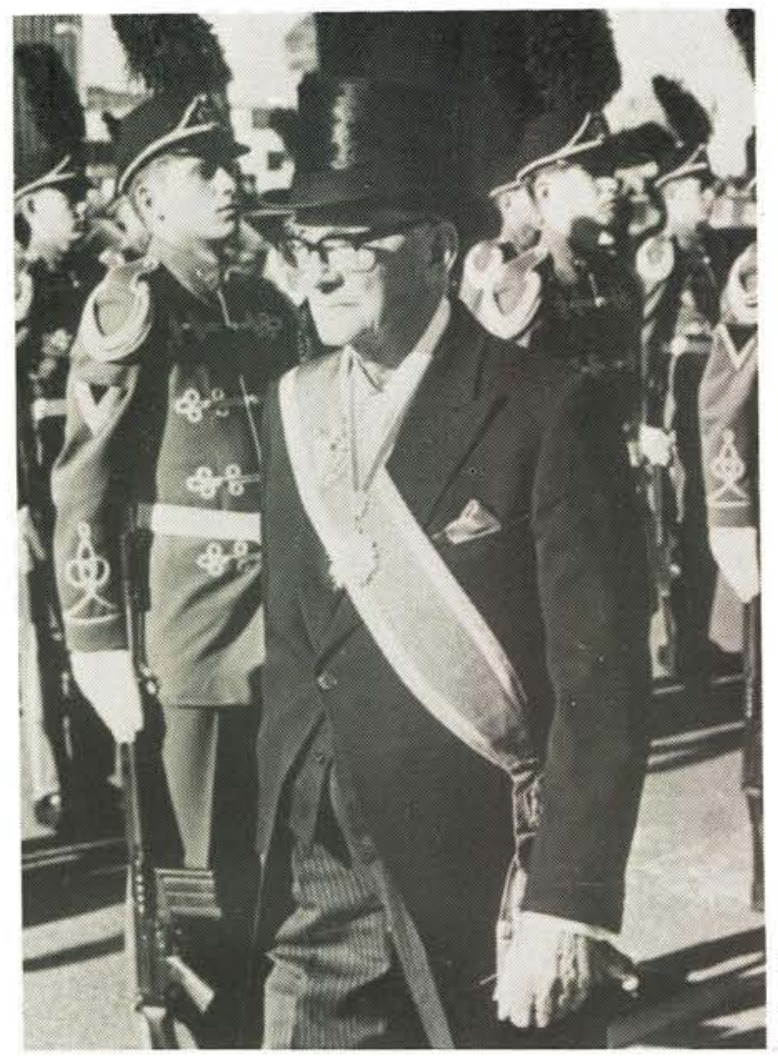

Mnr. J.J. Fouché, die RSA se tweede Staatspresident was inderwaarheid die eerste president onder wie die Staatspresidentswag gedien het.

Mr J.J. Fouché, the Republic of South Africa's second State President was, in fact, the first president to be served by the State President's Guard. 


\section{E. Dönges}

Due to serious illness, the State President-elect and successor of Mr Swart, Dr Eben Dönges, was never sworn in. The first performance of the State President's Guard was therefore not at his inauguration, but only eight months later at his state funeral in January 1968. nent foreign heads of state, ie President Banda of Malawi in 1971, and President Stroessner of Paraguay in 1974, as well as the visit of the Commander-in-Chief of the Portugese forces in Angola, Gen Joachim de luz Cunha, in 1972. The Guard also performed at the 1971 Republic Festival, at the opening of the Atlas Military Base of the Atlas Aircraft Corporation in 1972, and at the opening of UNISA in 1973.

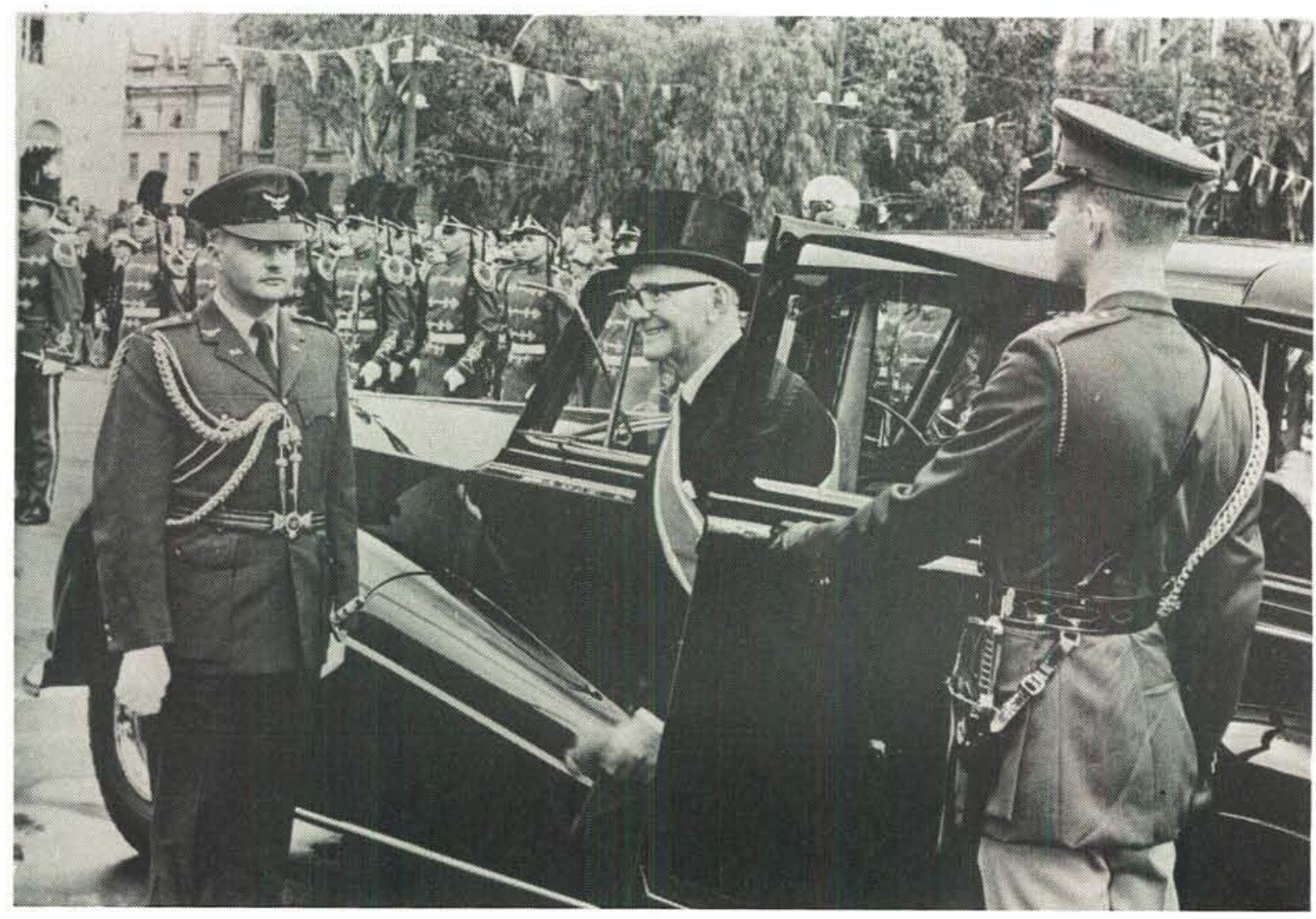

Mnr. Fouché arriveer vir die openingsfunksie by die Parlement in 1968.

Mr Fouché arrives for the opening ceremony at the Parliament building in 1968.

\section{J.J. Fouché}

The second State President of the Republic of South Africa, Mr J.J. Fouché was, in truth the first president to be served by the State President's Guard. Mr Fouché was the State President from 1968 to 1974 . In 1950 he was appointed Administrator of the Orange Free State, and nine years later he became the Minister of Defence. In 1968 , at the age of 69 , he became the second State President of South Africa.

The ceremonial performances of the State President's Guard during Mr Fouché's term of office include his inauguration, the visits of two emi-

\section{N. Diederichs}

The third State President of the RSA was the academic, financier, economist and statesman, Dr Nicolaas Diederichs. He will be remembered as 'Mister Gold', a name he earned during his term as Minister of Finance. In 1975 he was inaugurated as State President.

The performances of the State President's Guard during Dr Diederichs' term of office include his inauguration in 1975, and the Transkei Independence festival in 1976. In commemoration of the tenth birthday of the Guard in 1977 . 


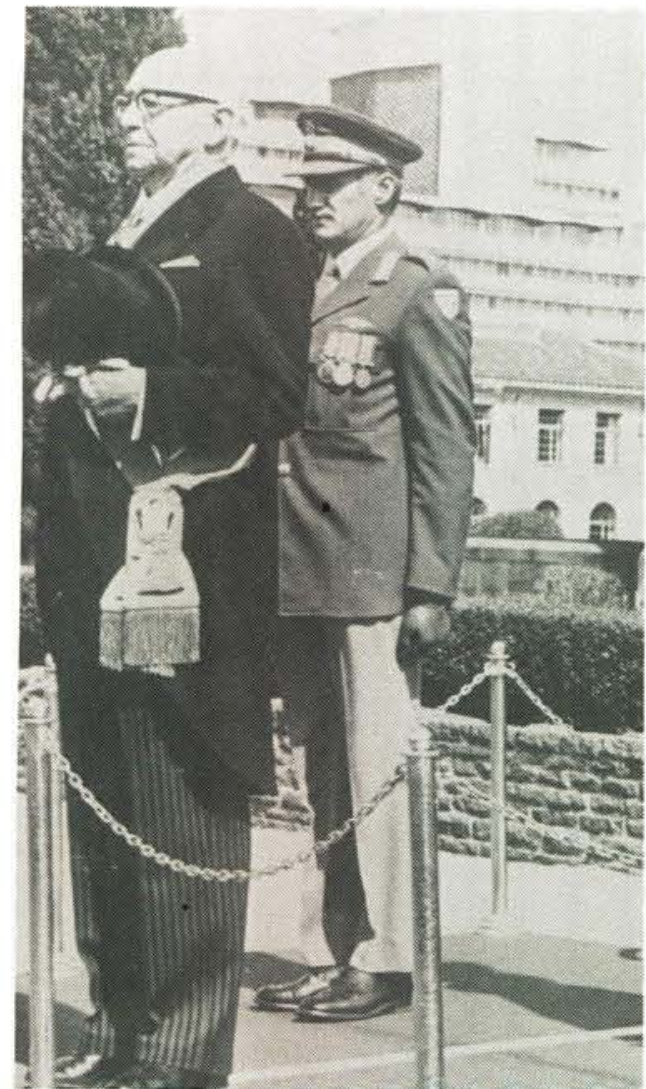

\section{President N. Diederichs neem die saluut tydens 'n} parade van die SP Wag in 1977.

\section{President $\mathrm{N}$. Diederichs takes the salute during a parade} of the State President's Guard in 1977.

parades were held, as well as a tea party with the State President. In the same year the Guard also performed at the opening of Loftus Versfeld, the unveiling of the statue of General J.B.M. Hertzog at the Union Buildings, and at the independence celebrations of the Republic of Botswana in December.

In 1978 one of the most outstanding performances of the Guard took place under less cheerful circumstances, namely at the state funeral of the then serving State President, Dr Diederichs.

\section{B.J. Vorster}

The successor of Dr Diederichs, Adv B.J. Vorster's political career commenced in 1953 as a Member of Parliament for Nigel. In 1958 he was appointed Deputy Minister; three years later he became Minister of Justice and in 1966 he was elected Prime Minister, a post which he held for the next 12 years.

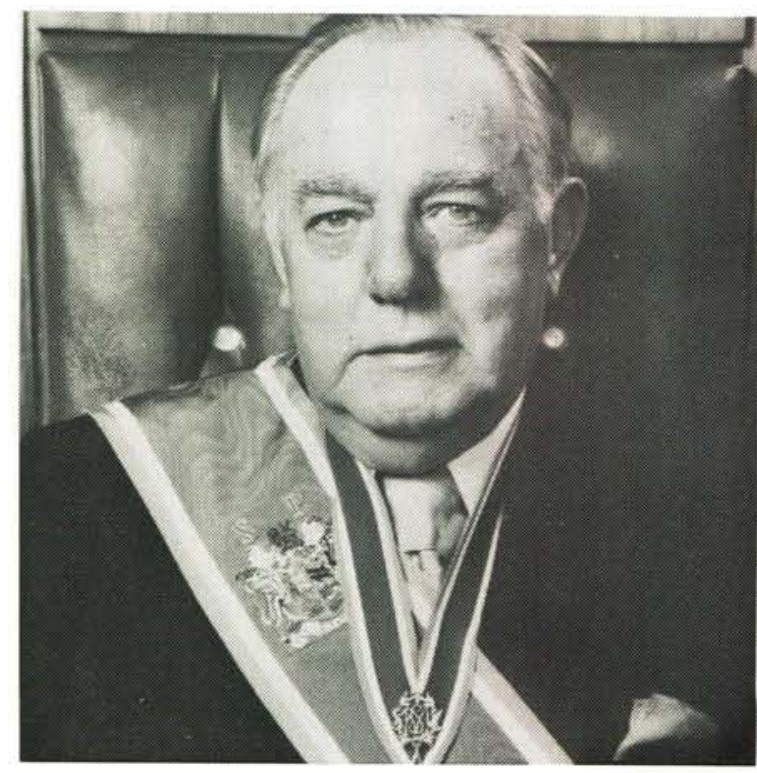

Adv. B.J. Vorster wat op 10 Oktober 1978 as Staatspresident ingehuldig is. Tydens die geleentheid het die Staatspresidentswag met groot luister opgetree.

Advocate B.J. Vorster who was inaugurated as State President on 10 October 1978. The performance of the State President's Guard lent much splendour to this occasion.

On 10 October $1978 \mathrm{Mr}$ Vorster was inaugurated as State President at Church Square, and the performance of the State President's Guard lent much splendour to the occasion. The last major public appearance of the Guard took place at the farewell party of Major-General H.K.J. van Noorden, SM, on 4 December 1978 at the Army College. In April 1979 the Castle's three-hundredth years of existence was celebrated. In commemoration of this, a military tattoo was organised, at which a display of the State President's Guard was given.

\section{Viljoen DVD}

The fifth and last State President under the Westminster system was the Capetonian, $\mathrm{Mr}$ Marais Viljoen. As Party Organiser, he was elected to the Provincial Council in 1949, after which he became a member of Parliament.

In 1958 he was appointed Deputy Minister, together with Messrs B.J. Vorster and P.W. Botha who respectively preceded and succeeded him as State President.

In 1966 he joined the Cabinet and held the portfolios of Labour and Coloured Affairs, and Post and Telecommunications. Ten years later he was appointed President of the Senate, in which 


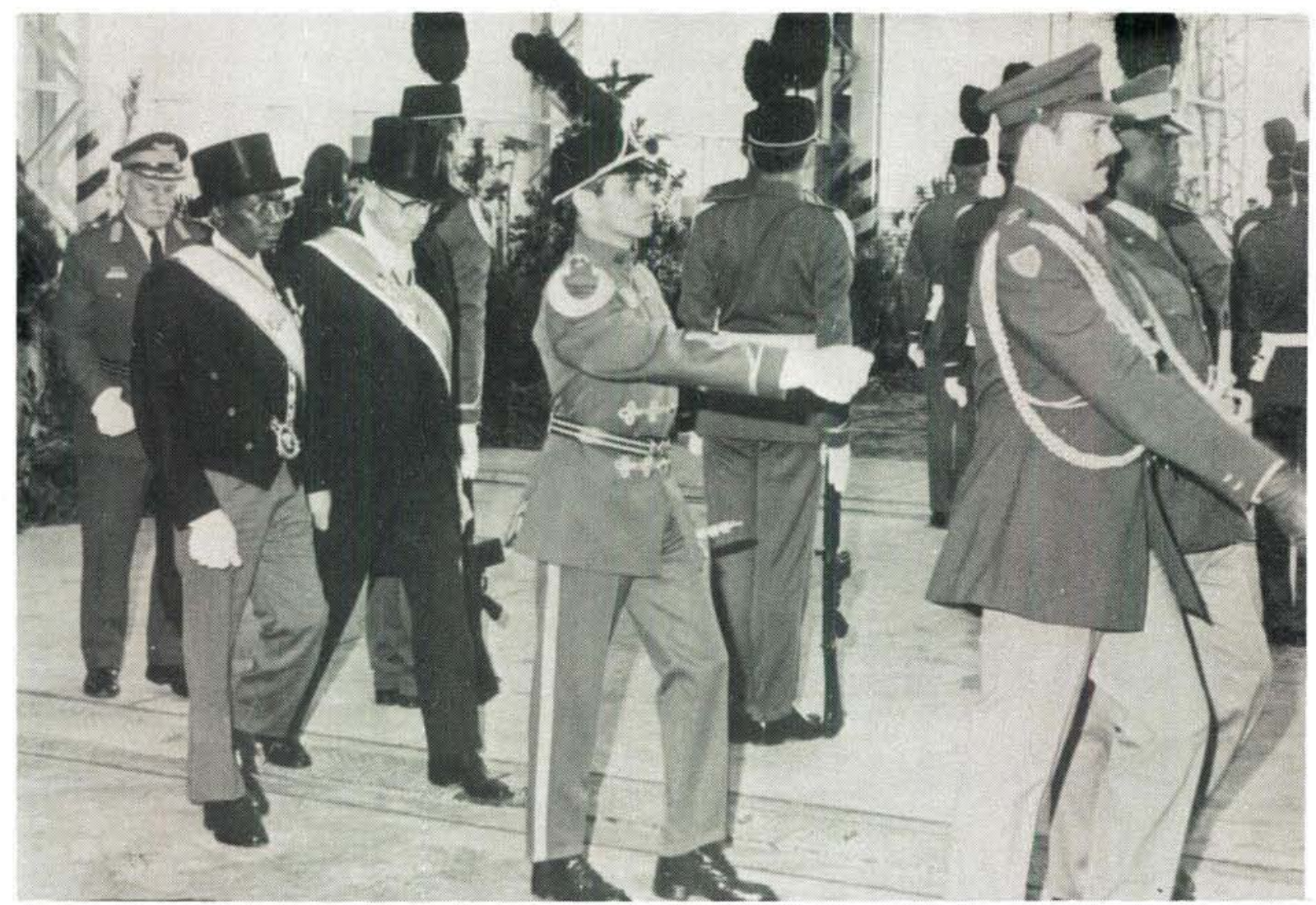

President M. Viljoen en President Mpephu stap in prosessie tydens die onafhanklikheidsvierings van Venda in 1981.

President M. Viljoen and President Mpephu move in procession during the Venda independence celebrations in 1981.

capacity he twice acted as State President. In June 1979 he was elected as the fifth State President of the RSA, a position which he held until the onset of the new dispensation in September 1984.

During Mr Viljoen's term of office, the first Durban Tattoo was held in 1979, during which the State President's Guard distinguished itself with a drill performance and mock attacks. This tattoo has now become a firmly established event. On 13 September 1978, Venda gained independence and at the celebrations in the Independence Stadium in Thoyandu, the Guard once again presented a brilliant display.

In 1980 South Africa lost another president. At the funeral of President Jim Fouché in Bloemfontein the Guard once again walked ahead of the gun carriage. In 1980 the Prime Minister, Mr P.W. Botha paid an official visit to Taiwan and on his return, the Guard formed part of a guard of honour to welcome him at Waterkloof Air Force Base.

Upon General Neil Webster's retirement, the
Guard performed at his farewell parade. The Guard acted as part of a guard of honour at the funeral of the former Chief of the Army, Lieutenant-General Willem Louw on 8 July 1980.

At the inauguration of the State Theatre in 1981 , the Guard performed a retreat ceremony. In the same year the country was visited by President Matanzima of the Transkei and later by President Mpephu of Venda. Both were welcomed by the State President's Guard at a reception parade.

On 4 December 1981, the Ciskei also gained independence, and the Guard performed at these festivities as well, during which the flagpole collapsed several times!

Apart from the reception parade of President Viljoen on 2 January 1982 and the Opening of Parliament on 29 January, the Guard also performed later in the year at the presentation of the Freedom of the City to the State President by the City Council of Vryburg, as well as at the farewell parade of Major-General Fourie at the grounds of the Army College. 


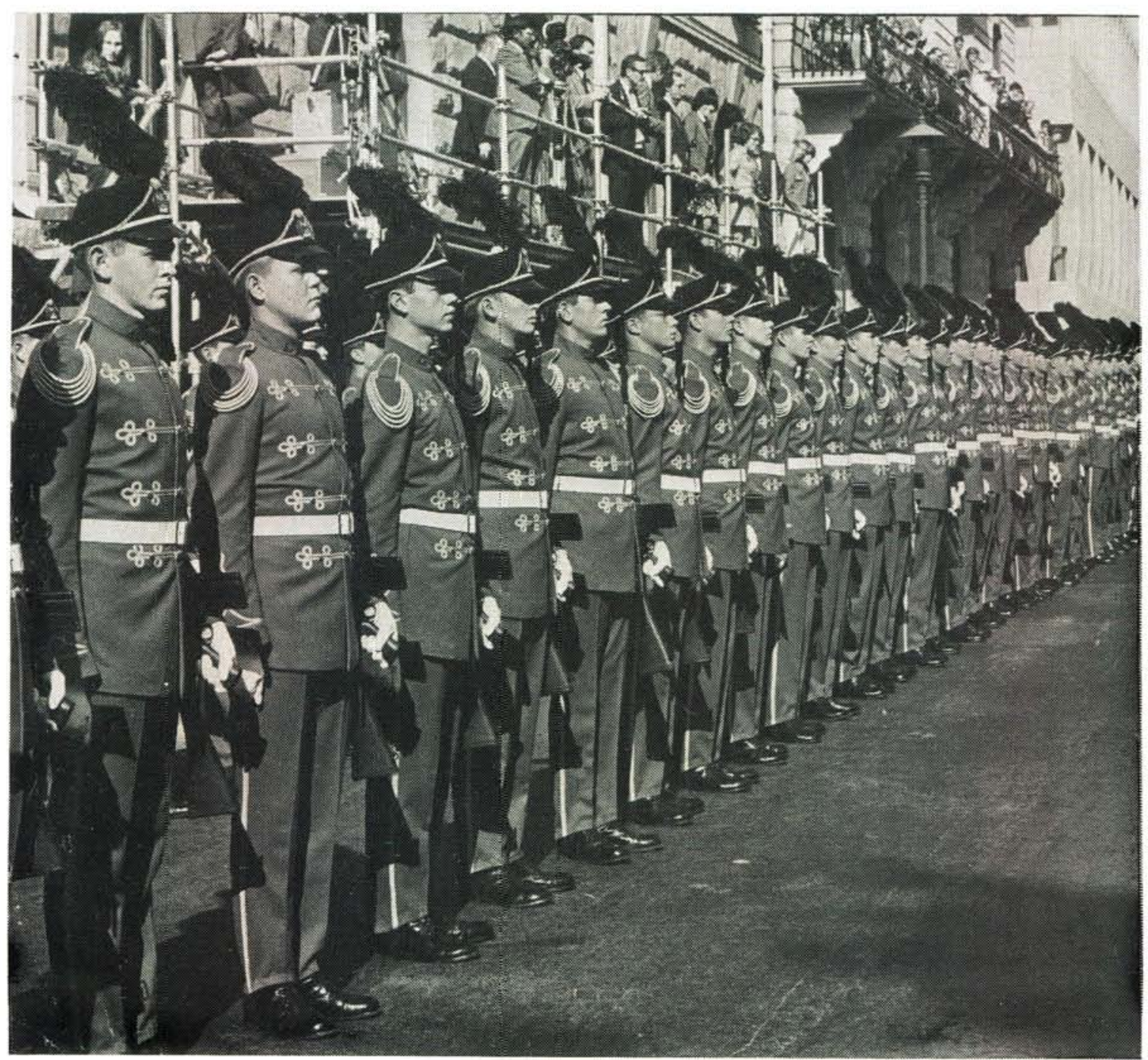

Optrede van die Wag by die Opening van die Parlement.

Display of the Guard at the Opening of Parliament.

The first State President, Mr C.R. Swart died in July 1982 and the Guard performed at his funeral on 22 July. He was the only State President not to be served by the Guard during his term of office.

The performances of 1983 commenced with the Opening of Parliament. Other performances during 1983 included; the parade held in honour of the State President on 15 October in Pretoria; the presentation of the new army uniform to the Chief of the South African Defence Force; a drill display at the Piet Retief Army Day; as well as the welcoming of the Minister of Defence and a performance at the Pretoria Show.

For the State President's Guard, 1984 proved to be an eventful year. As usual, the Opening of Parliament was the first of the Guard's annual performances. Other highlights in the diary of the State President's Guard were the opening of the Southern Cross Fund's carnival in the Cape, an Army Day at Barberton and the signing of the Nkomati Accord. 


\section{UNIFORM OF THE STATE PRESIDENT'S GUARD

\author{
UNIFORMS VAN DIE \\ STAATSPRESIDENTSWAG
}

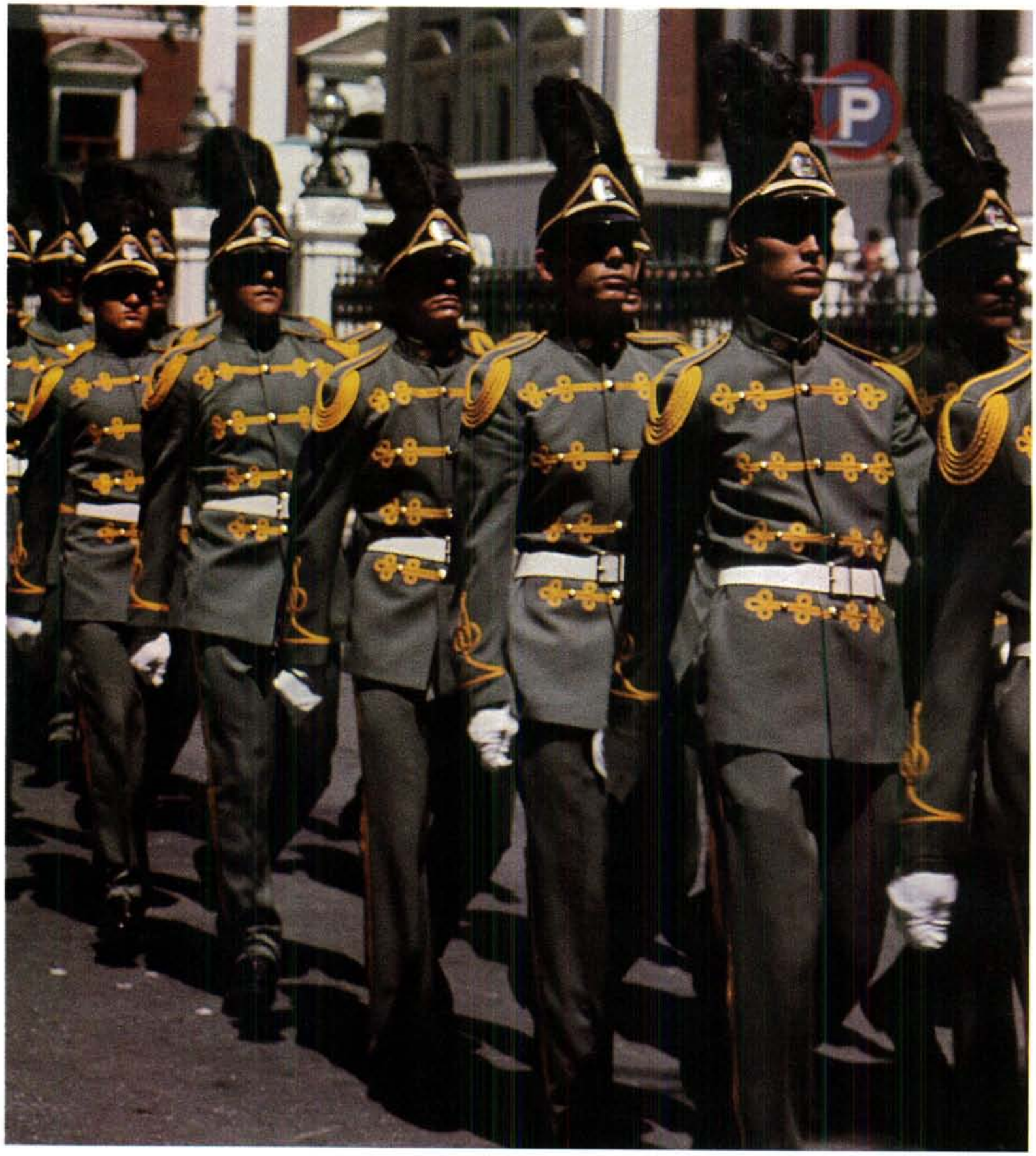

SP Wag op parade tydens die opening van die Parlement, Januarie 1985.

State President' Guard on parade during the Opening of Parliament, January 1985. 


\section{NEW UNIFORM OF THE STATE PRESIDENT'S UNIT SINCE 1985 NUWE UNIFORM VAN STAATSPRESIDENTSEENHEID SEDERT 1985}

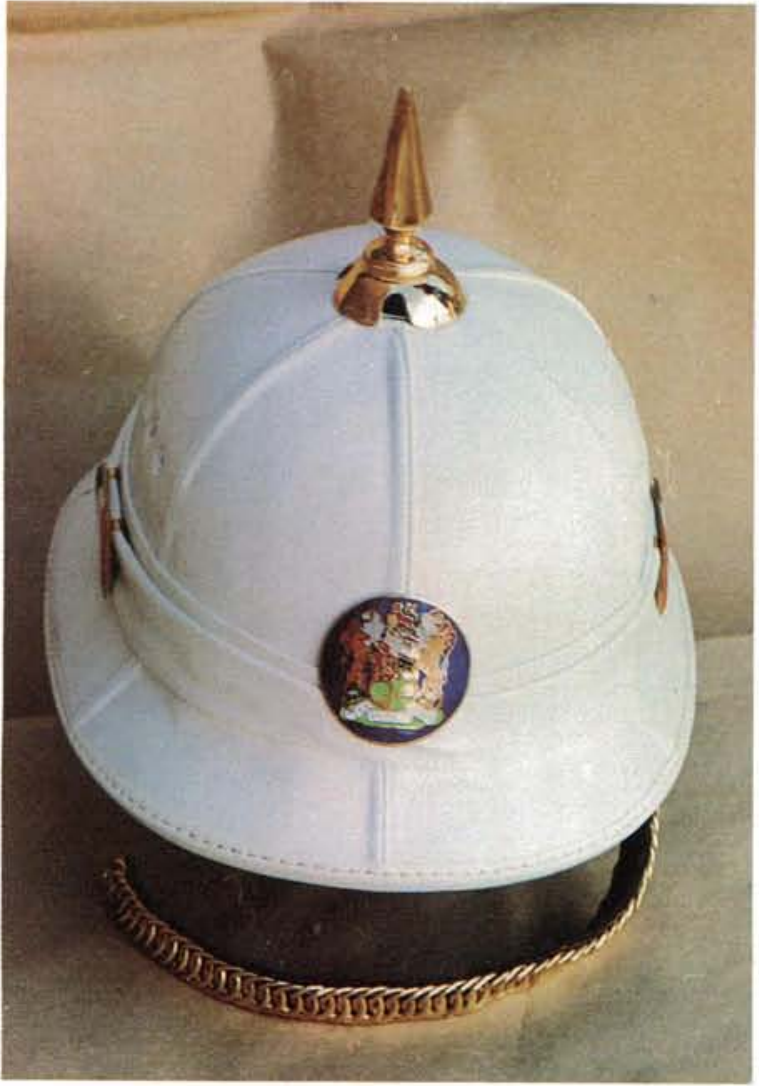

Wit punthelmet met penteken voorop. White cork helmet with spike.

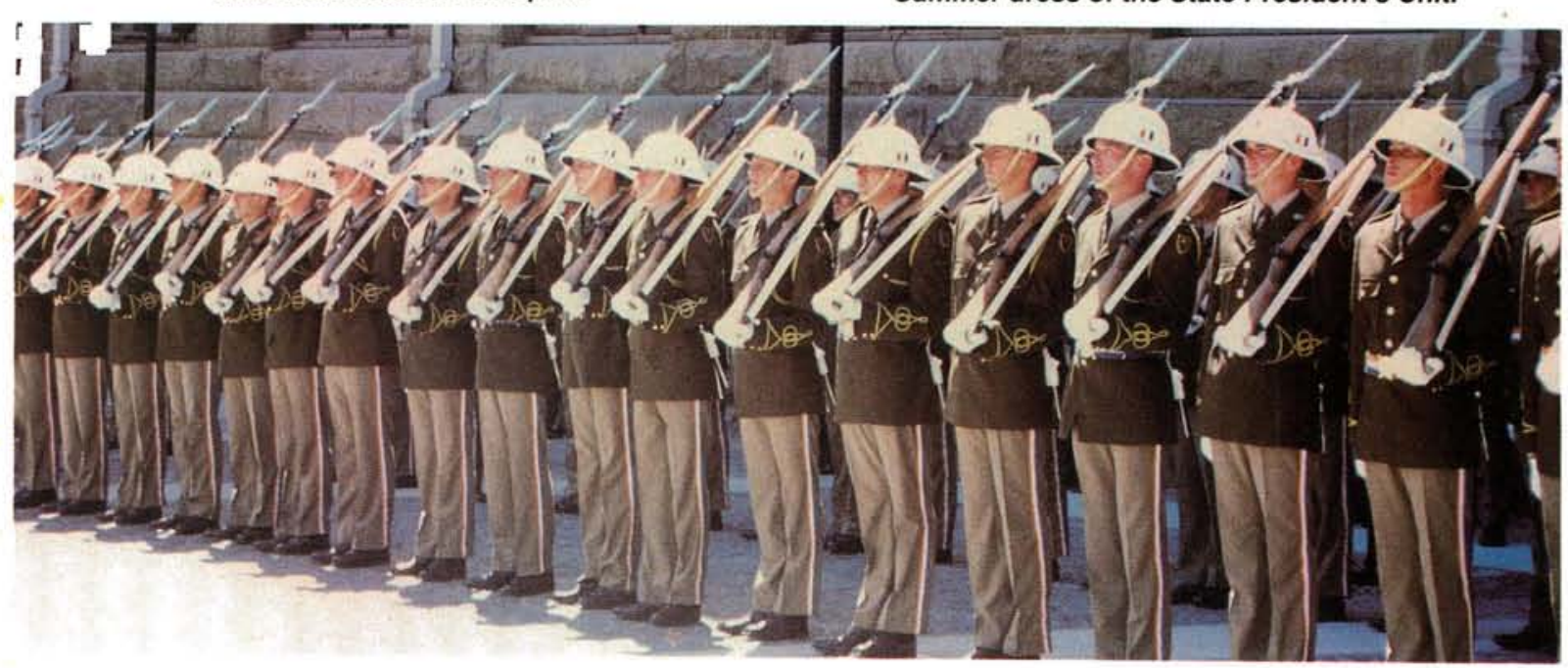

SP-eenheid in seremoniële en paradedrag tydens opening van Parlement, Januarie 1986.

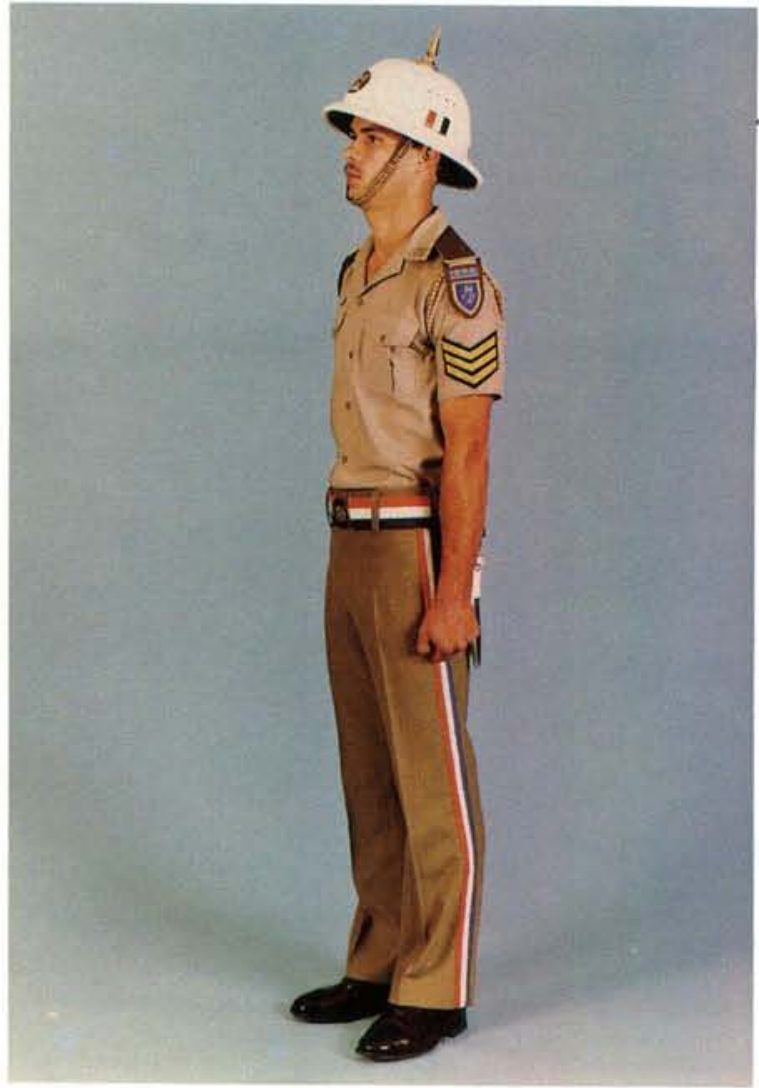

Somersdrag van SP-eenheid. Summer dress of the State President's Unit. January 1986.

State President's Unit in ceremonial and parade dress during the Opening of Parliament, 


\section{P.W. Botha}

The first State President under the new dispensation was Mr P.W. Botha, who was elected to the House of Assembly in 1948, and 10 years later became Deputy Minister. In 1961 he was appointed cabinet minister with the portfolios Community Development and Coloured Affairs.
In 1966 he was appointed leader of the National Party in the Cape, as well as Minister of Defence, a post which he held until 1980. In 1978, Mr Botha was elected Prime Minister, a position which he held until he was appointed State President under the new dispensation on 3 September 1984.

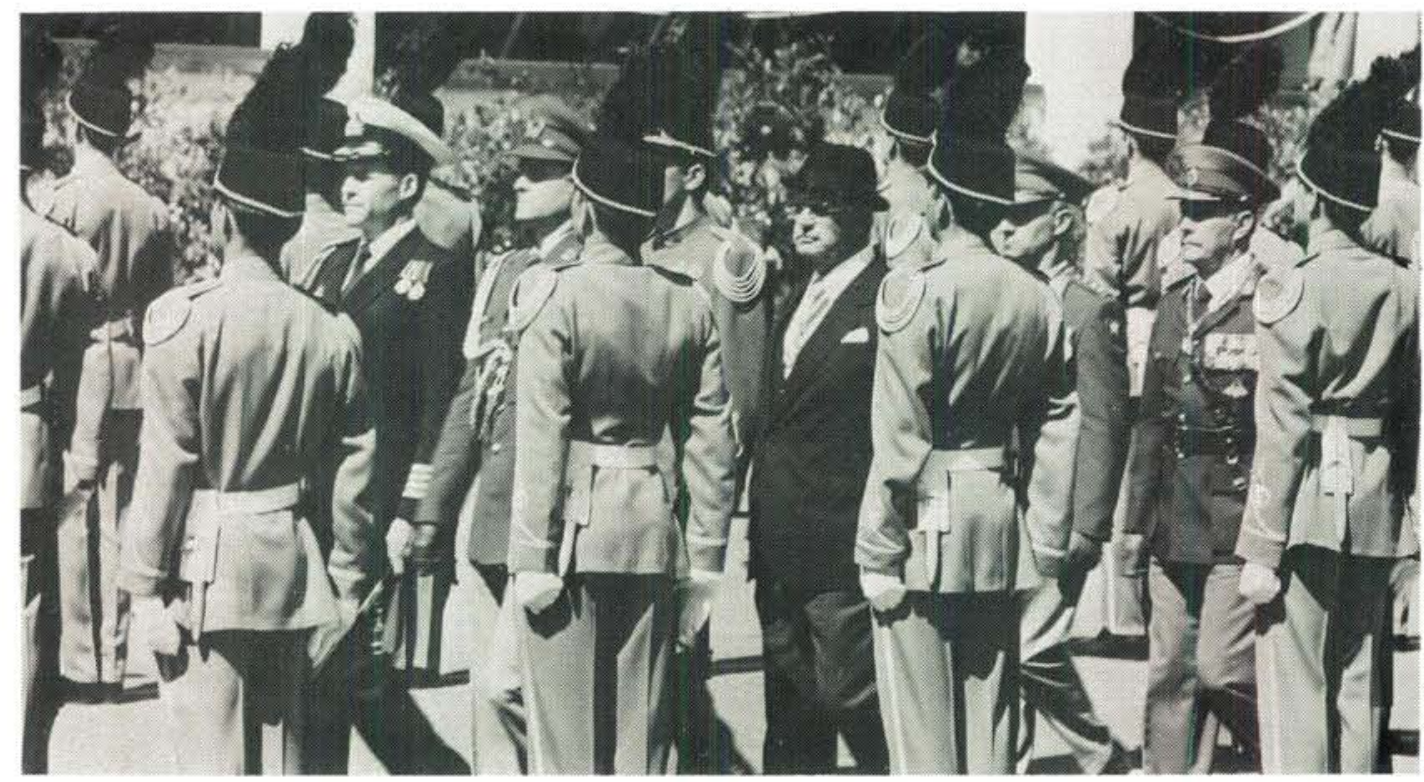

Inhuldigingseremonie van mnr P.W. Botha, eerste President in die nuwe bedeling op 14 September 1984 in Kaapstad. Inauguration ceremony of Mr P.W. Botha, the first State President under the new dispensation, on 14 September 1984 in Cape Town.

On 14 September he was inaugurated as State President at a splendid parade in the Cape, during which the State President's Guard also performed. Other performances in that year were the reception of the State President in Pretoria; an inspection parade for the Ciskei Minister of Defence in Pretoria; as well as acting during the riots at Sebokeng in October.

In January 1985 the Guard performed at the Opening of Parliament and at the opening of a new complex of the Army College. A drill display was also held at the Eldoraigne School and at the Pretoria Show.

The Unit is also responsible for a weekly changing of the guard parade on Fridays at Tuynhuys in Cape Town while Parliament is in session. At the end of each month, a retreat ceremony is held by the Unit at a public venue. Similar parades have been held at the Castle, the Parade in Cape Town and at the Union Buildings in Pretoria.
Although the primary task of the State President's Guard is to act as home guard for the State President and as guard of honour on ceremonial occasions, they also do border duty. Consequently, the training of the Unit is quite diverse and intensive and the requirements for selection are very strict.

- Lt Cdr E.M. Meyers, MA (HOD) is attached to the Military Information Bureau, SADF.

\section{Bibliography}

1. Beeld, 29.9.1980. Hulde aan die Boere Edelman.

2. Burger, 23.9.1980. Pres Fouché Oorlede.

3. Burger, 24.8.1980. Oom Jim se Politieke Siklusse.

4. Rand Daily Mail, 24.9.1980. Oom Jim Leaves SA a Warm Memory.

5. E.A. Venter, 400 Leiers in Suid-Afrika oor Vier Eeue, Potchefstroom, 1980.

6. Argus Printing and Publishing Co, Who's Who of Southern Atrica, Johannesburg.

7. SADF Documentation Service. Die Staatspresidentswag 15 Jare 1982. 